\title{
THE EFFECT OF AN AUGMENTED REALITY TEACHING KIT ON VISUALIZATION, COGNITIVE LOAD AND TEACHING STYLES
}

\author{
Mohd Erfy Ismail ${ }^{1}$, Pipit Utami ${ }^{2}$, Irwan Mahazir Ismail ${ }^{3}$, Moh. Khairudin ${ }^{4}$, \\ Mohd Hasril Amiruddin ${ }^{5}$, Badraningsih Lastariwati ${ }^{6}$ and Nopadon Maneetien ${ }^{7}$ \\ ${ }^{1,3,5}$ Faculty of Technical \& Vocational Education, Universiti Tun Hussein Onn Malaysia, Malaysia \\ 2,4,6Faculty of Engineering, Universitas Negeri Yogyakarta, Indonesia \\ ${ }^{7}$ Faculty of Engineering, Rajamangala University of Technology Lanna, Chiang Mai, Thailand \\ E-mail: erfy@uthm.edu.my
}

\begin{abstract}
The purpose of this study was to identify the visualization of the students, the students' cognitive load, and the teaching style of the teacher while teaching using the augmented reality (AR) teaching kit in the classroom. The population involved 90 Welding Technology students at Vocational College of Batu Pahat. The purposive sampling method was used and involved 30 respondents. The instrument used was a questionnaire to obtain information. Data were collected and analyzed descriptively. Based on the pilot study, the Cronbach Alpha value was 0.94. The results showed that the use of an AR teaching kit was able to enhance students' visualization and reduced the cognitive load experienced by the students. In addition, teaching and learning are more interesting because of the teaching style of teachers who use theories and practices simultaneously. Furthermore, the use of AR in education can enhance the visualization of students abstractly, which helps them when conducting experiential tests and establishing a safe teaching and learning environment.
\end{abstract}

Keywords: augmented reality, cognitive load, teaching style, technical and vocational education, visualization

\section{INTRODUCTION}

Technical and Vocational Education (TVE) is a training-oriented approach to education and emphasizes what needs to be done at the workplace as a learning outcome either to meet work needs or to improve students' performance to the required skill level. According to Kersten [1], TVE is also an educational system that provides specialized training in technical skills and some other skills.

Nowadays, TVE has begun providing exposure to virtual learning in vocational-based learning. Virtual learning provides a virtual environment for students to learn and communicate with each other through a device interface [2]. Therefore it can show them new ways of communication. Students could gather information by interacting with virtual characters and by acquiring virtual data from authentic resources and tools (teaching kit) embedded in the system [3]. According to Howard et al. [4], technology has been used as a bridge between students' experience and existing knowledge with newly learned and learned knowledge, ironically, the rapid development of technology now challenges teachers to implement technology in teaching. Sung et al. [5] claimed that the learning method using a teaching kit allows learning to happen at any time, especially their skill in TVE. Thus, the teachers teaching style with the new technology of a teaching kit helps them facilitate the teaching process for skill subject.

Furthermore, the less effective teaching style of teachers has a negative impact on the students' understanding. Therefore, the core of student excellence may be on the use of a teaching kit by teachers. To understand each of the contents of a practical lesson, students need to do the task themselves to master the skills [6]. Teacher-centered learning has the effect that students receive only the information that the teacher delivers and is less aware of the subject matter of the subject they learn [7]. The cause of difficulty in mastering this subject is that the teaching session is less attractive. This may be because most teaching and learning are only centered on teachers and students weak in interpretation in the form of visualization. 
Olshannikova et al. [8] explain that the goal of visualization is to present data in ways to make things clearer by involving the human sensory system and the key to visualization is information that can be collected and interpreted directly to the sensory input. Furthermore, a teacher who uses a traditional teaching method, make students difficult to visualize the types of welding defects according to the shape and appearance of the defect [9]. Besides, according to Hodgkiss et al. [10], spatial visualization also involves the ability to identify, retain, process and recall the stimulus of knowledge. The student with low spatial ability requires memory to process more than the student with high spatial ability. The impression, cognitive load of the low spatial ability students, will increase because cognitive capacity in working memory is limited [11].

The cognitive load is one of the problems that causes less students stimulation towards learning [12]. This is because students cannot relate theory and practice as a whole [13]. Given the limited working memory capacity, students cannot focus on the lesson content and difficult task assignments simultaneously [14]. Thus the problem arises that the student is unaware of the problem presentation. If the task or learning activity requires cognitive capacity beyond its limit, learning will become obstructed [11]. Therefore, learning strategies that optimize the allocation of cognitive resources are essential to determine the effectiveness of such learning strategies.

This study will analyze the visualization of the students, the students' cognitive load, and the teacher teaching style resulted from the benefits of using an augmented reality (AR) teaching kit in the classroom. The AR teaching kit is expected to be an innovative approach that will improve the teaching learning process.

\section{METHOD}

The research methodology is determined by the design of the study through a survey. It used the method of quantitative research using questionnaires as the instrument to get the data and information for answering the research questions [15]. The survey is comprehensive, which may comment on the issue from various points of views, how easy handling can accumulate and collect data quickly corresponding to the large sample size, the information obtained directly and able to make decisions collectively.

The population in this study included 90 respondents consisting of male and female students from the first year students in the Welding Technology courses at Batu Pahat Vocational College, which comprises the entire study population involved in doing practical works in the welding technology laboratory. The sample used was purposive sampling. The sampling aimed where researchers choose an example to obtain 30 samples of the total population [15].

In this study, the validity was made to ensure the questionnaire can be used. A content expert and product development expert were used in this study to make sure the instrument's validity. Moreover, the pilot study was carried out to obtain the reliability of the questionnaire. Based on the analysis that has been made, Alpha Cronbach value was 0.94 categorized as a high level.

The real data obtained from the questionnaires were collected and analyzed descriptively. The mean score analysis was presented in Table 1. Based on the analysis of the mean at the level of high, medium and low can be shown that the answer is assessed through the counting $\operatorname{Min}=\Sigma \mathrm{x} / \mathrm{n}$. Table 1 
shows the interpretation of mean score derived from the data [16].

Table 1. Interpretation of Mean Value

\begin{tabular}{cc}
\hline The Range of Mean Value & Interpretation \\
\hline 1.00 to 2.00 & Low \\
2.01 to 3.00 & Medium \\
3.01 to 4.00 & High \\
\hline
\end{tabular}

\section{RESULTS AND DISCUSSION}

Table 2 reports that the mean value of students' visualization is high. The respondents agreed that the AR teaching kit could improve the students' visualization. According to Said et al. [17], the AR teaching kit enhanced student visualization through three dimensions namely graphs, representations, and real objects.

Table 2. Mean Value and Standard Deviation of Students' Visualization

\begin{tabular}{|c|c|c|c|}
\hline Number & Items & Mean & $\begin{array}{c}\text { Standard } \\
\text { Deviation }\end{array}$ \\
\hline A1 & $\begin{array}{c}\text { The video increases } \\
\text { visualization a real } \\
\text { object }\end{array}$ & 3.73 & 0.45 \\
\hline A2 & $\begin{array}{l}\text { The video helps } \\
\text { students in } \\
\text { visualizing the } \\
\text { welding defects }\end{array}$ & 3.73 & 0.45 \\
\hline A3 & $\begin{array}{l}\text { Graphics } \\
\text { presentations help in } \\
\text { visualization skills }\end{array}$ & 3.69 & 0.50 \\
\hline A4 & $\begin{array}{l}\text { AR teaching kit can } \\
\text { help in the use of } \\
\text { visualization skills }\end{array}$ & 3.70 & 0.49 \\
\hline A5 & $\begin{array}{l}\text { The AR learning } \\
\text { method used can } \\
\text { improve the } \\
\text { visualization }\end{array}$ & 3.69 & 0.50 \\
\hline A6 & $\begin{array}{l}\text { Easy to interpret the } \\
\text { visual using the AR } \\
\text { teaching kit }\end{array}$ & 3.68 & 0.48 \\
\hline
\end{tabular}

Table 3 shows that the mean value on the student's cognitive load is high. This indicates that the respondents agreed that the AR teaching kit could help respondents in reducing their cognitive load. This is also supported by Lin \& Lin [18] which is cognitive loads faced by students can be solved through the appropriate medium.

Table 4 records that the mean value of teachers' teaching style is high. This indicates that the students agreed that the AR teaching kit of welding defect toward teachers' teaching style could help students in learning skill subjects in the classroom. Besides, a good teaching kit must meet its features, the suitability of the material with the contents of the taught lessons is important to ensure that the content of the lesson is presented clearly to the students, so that the student's strength, clarity, and attractiveness must be fulfilled.

Table 3. Mean Value and Standard Deviation of Students' Cognitive Load

\begin{tabular}{|c|c|c|c|}
\hline Number & Items & Mean & $\begin{array}{c}\text { Standard } \\
\text { Deviation }\end{array}$ \\
\hline B1 & $\begin{array}{l}\text { AR teaching kit will } \\
\text { reduce the cognitive } \\
\text { load while learning }\end{array}$ & 3.43 & 0.51 \\
\hline B2 & $\begin{array}{c}\text { The video easily } \\
\text { illustrate the subject } \\
\text { being taught }\end{array}$ & 3.63 & 0.47 \\
\hline B3 & $\begin{array}{l}\text { Students can absorb } \\
\text { learning content } \\
\text { more effectively }\end{array}$ & 3.57 & 0.49 \\
\hline B4 & $\begin{array}{l}\text { AR teaching kit } \\
\text { does not burden } \\
\text { students in learning. }\end{array}$ & 3.53 & 0.49 \\
\hline B5 & $\begin{array}{l}\text { AR teaching kit } \\
\text { could store the } \\
\text { memory longer }\end{array}$ & 3.57 & 0.48 \\
\hline B6 & $\begin{array}{l}\text { AR teaching kit } \\
\text { help student to } \\
\text { understand the } \\
\text { complex part in } \\
\text { learning }\end{array}$ & 3.73 & 0.45 \\
\hline
\end{tabular}

Table 4. Mean Value and Standard Deviation of Teachers' Teaching Style

\begin{tabular}{|c|c|c|c|}
\hline Number & Items & Mean & $\begin{array}{c}\text { Standard } \\
\text { Deviation }\end{array}$ \\
\hline $\mathrm{C} 1$ & $\begin{array}{l}\text { Teachers can attract } \\
\text { students' attention } \\
\text { effectively }\end{array}$ & 3.60 & 0.50 \\
\hline $\mathrm{C} 2$ & $\begin{array}{l}\text { While teaching, } \\
\text { teachers give fair } \\
\text { attention to all } \\
\text { students }\end{array}$ & 3.60 & 0.50 \\
\hline $\mathrm{C} 3$ & $\begin{array}{c}\text { Easy to understand } \\
\text { the topic that taught } \\
\text { by teachers }\end{array}$ & 3.57 & 0.50 \\
\hline $\mathrm{C} 4$ & $\begin{array}{l}\text { Teachers offer } \\
\text { students an } \\
\text { opportunity to ask } \\
\text { questions }\end{array}$ & 3.63 & 0.49 \\
\hline $\mathrm{C} 5$ & $\begin{array}{l}\text { The teaching style } \\
\text { delivered by the } \\
\text { teachers is } \\
\text { interesting }\end{array}$ & 3.63 & 0.49 \\
\hline C6 & $\begin{array}{l}\text { Teachers give a } \\
\text { clear picture of the } \\
\text { topic being taught }\end{array}$ & 3.77 & 0.43 \\
\hline
\end{tabular}


The use of technology such as AR teaching kit is helpful in understanding students' issues such as visualization, cognitive loads and teacher teaching styles. The use of technology applied in teaching kit helps students understand the type of welding defects found in specimens. The whole design is the result of thought and experimentation. Comfort and usability factors are emphasized in its construction.

The findings show that this AR teaching kit can help students in improving their visualization skills. According to Özerem \& Akkoyunlu [19], Purwono [20] and Sari [21] learning from visual language, visual number, and auditory language allow each of these learning to be easy and students can remember what they are learning. Multimedia elements are the best way of delivering subject content that requires visual support [22], [23]. The use of AR in this teaching kit gives students a new experience where users can interact with the virtual world for information from audio, graphics, videos and texts that have been developed. According to Saidin et al. [24] and Cheng [25], AR can provide teachers with ways to reinforce students' understanding in the classroom with the use of visual tools and illustrations [26]. The use of AR is particularly useful as a platform to develop a teaching kit that requires student visualization.

Multimedia technology helps students explore their learning to study and discover ideas after making appropriate judgments [27]. Thus, the teaching kit was developed using multimedia embedded with AR technology that can help students in improving visual. Also, multimedia technologies such as graphics and animation enhance memory capability, affect social interaction and help master visualization skills [28]. According to Hasan \& Ali [29], existing features such as animation, videos, sound, texts, audio, and graphics can stimulate the student's mind and bring significant impact to communication and education. The existence of these elements can attract students' attention throughout the teaching and learning process as if they were able to communicate with students [30].

Furthermore, learning through this AR teaching kit found that students will not be burdened with the teaching taught by the teacher. Also, the use of teaching kit by the teacher during the teaching and learning process will help improve the cognitive and affective quality of the students [31]. Moreover, the design of the teaching kit has been able to optimize the use of student's working memory capacity and avoid cognitive overload [11]. This shows that the teaching kit works well and helps students and teachers in the teaching and learning process.

The use of an appropriate teaching kit can facilitate teachers in teaching, stimulation, motivation, attract students' interest in mastering skills and directly improving academic achievement among students [32]. The advantage of using AR is to allow students to imagine objects and concepts that are invisible to the naked eye [33]. AR envisions ideas and objects in various ways and perspectives which enable students to master the subject [34]. In addition, AR also allows students to become active in the learning process as well as to think creatively and critically that can enhance their understanding of learning [14].

The results of the study on the teaching style of the teacher through this AR teaching kit found that the teaching style of the teacher was positive motivation in student learning [35]. According to Ngah [36], teaching and learning processes in the classroom need to be gradually designed according to the level of the students thus students can easily follow the contents of the lesson. Suryanto et al. [37] stated that teachers could explain the content more efficiently and the students more clearly understand about the weld defects process. A good understanding will also impact on improving student learning outcomes [38]. This shows that the use of an AR teaching kit can provide more insight than teachers' teaching styles that are solely based on teachers. In 
addition, the use of a teaching kit as teaching kit makes teaching and learning more interesting [39]-[41].

Moreover, teachers need to be more creative when planning their teaching. The teacher's teaching style must be in line with the students' ability. In addition, the teacher should actively involve students in the teaching and learning process, and this requires a high level of teaching skills among teachers [42]. Traditional pattern approaches and chalk and talk are less relevant to the needs of today's students [42]. Creative teachers are educators who can structure educational experiences that enable the development of creativity among their students. Creative teachers can demonstrate flexibility in the selection of approaches, teaching strategies or pedagogy in carrying out their role [43].

\section{CONCLUSION}

Overall, the AR teaching kit of welding defect helps the students in visualization. The findings shows that the AR teaching kit enhanced the students visualization through three dimensions namely graphs, representations, and real objects. It enhances the visualization of students abstractly, which helps them when conducting experiential tests and establishing a safe teaching and learning environment. It also helps the students in reducing their cognitive load and facilitates teachers throughout the teaching and learning process to create learning independently. Furthermore, the AR teaching kit could be a groundbreaking approach that will change the teaching and learning to be more interesting because the teachers use theories and practices simultaneously.

\section{REFERENCES}

[1] S. Kersten, "Approaches of Engineering Pedagogy to Improve the Quality of Teaching in Engineering Education," Springer, Cham, 2018, pp. 129-139.
[2] V. Potkonjak et al., "Virtual Laboratories for Education in Science, Technology, and Engineering: A Review," Comput. Educ., vol. 95, pp. 309-327, Apr. 2016.

[3] H.-K. Wu, S. W.-Y. Lee, H.-Y. Chang, and J.-C. Liang, "Current Status, Opportunities and Challenges of Augmented Reality in Education," Comput. Educ., vol. 62, pp. 41-49, Mar. 2013.

[4] S. K. Howard, J. Ma, and J. Yang, "Student Rules: Exploring Patterns of Students' Computer-Efficacy and Engagement with Digital Technologies in Learning," Comput. Educ., vol. 101, pp. 29-42, Oct. 2016.

[5] Y.-T. Sung, K.-E. Chang, and T.-C. Liu, "The Effects of Integrating Mobile Devices with Teaching and Learning on Students' Learning Performance: A Meta-Analysis and Research Synthesis," Comput. Educ., vol. 94, pp. 252-275, Mar. 2016.

[6] N. A. Mamaril, E. L. Usher, C. R. Li, D. R. Economy, and M. S. Kennedy, "Measuring Undergraduate Students' Engineering Self-Efficacy: A Validation Study," J. Eng. Educ., vol. 105, no. 2, pp. 366-395, Apr. 2016.

[7] S. Altun, "The Effect of Cooperative Learning on Students' Achievement and Views on the Science and Technology Course," Int. Electron. J. Elem. Educ., vol. 7, no. 3, pp. 451-468, 2017.

[8] E. Olshannikova, A. Ometov, Y. Koucheryavy, and T. Olsson, "Visualizing Big Data with Augmented and Virtual Reality: Challenges and Research Agenda," J. Big Data, vol. 2, no. 1, pp. 1-27, 2015.

[9] C. A. Bodnar, D. Anastasio, J. A. Enszer, and D. D. Burkey, "Engineers at Play: Games as Teaching Tools for Undergraduate Engineering Students," $J$. Eng. Educ., vol. 105, no. 1, pp. 147200, Jan. 2016.

[10] J. Wiley, A. Hodgkiss, K. A. Gilligan, A. K. Tolmie, M. S. C. Thomas, and E. K. Farran, "Spatial Cognition and Science Achievement: The Contribution of Intrinsic and Extrinsic Spatial Skills from 7 to 11 years," $B r$. J. Educ. Psychol., pp. 1-23, 2018. 
[11] T. De Jong, "Cognitive Load Theory, Educational Research, and Instructional Design: Some Food for Thought," Instr. Sci., vol. 38, no. 2, pp. 105-134, 2010.

[12] P. Chen, X. Liu, W. Cheng, and R. Huang, "A Review Of Using Augmented Reality in Education from 2011 to 2016," Innov. Smart Learn., pp. 13-18, 2017.

[13] J. C. Chen, "Teaching Nontraditional Adult Students: Adult Learning Theories in Practice," Teach. High. Educ., vol. 19, no. 4, pp. 406-418, May 2014.

[14] O. Chen, J. C. Castro-Alonso, F. Paas, and J. Sweller, "Extending Cognitive Load Theory to Incorporate Working Memory Resource Depletion: Evidence from the Spacing Effect," Educ. Psychol. Rev., vol. 30, no. 2, pp. 483501, Jun. 2018.

[15] L. Cohen, L. Manion, and K. (Keith R. B. Morrison, Research Methods in Education. Routledge, 2017.

[16] W. Wiersma and S. G. Jurs, Research Methods In Education: An Introduction, 9th ed. Boston: Allyn \& Bacon, 2009.

[17] C. S. Said, I. N. Umar, B. Muniandy, S. Desa, and H. F. Hanafi, "Effects of the Metaphor in Algebra Learning among Students in Lower Secondary," $J$. Pendidik. Sains dan Mat. Malaysia (JPSMM UPSI), vol. 5, no. 1, pp. 57-69.

[18] Y.-T. Lin and Y.-C. Lin, "Effects of Mental Process Integrated Nursing Training Using Mobile Device on Students' Cognitive Load, Learning Attitudes, Acceptance, and Achievements," Comput. Human Behav., vol. 55, no. Part B, pp. 12131221, Feb. 2016.

[19] A. Ozerem and B. Akkoyunlu, "Learning Environments Designed According to Learning Styles and Its Effects on Mathematics Achievement*," Eurasian J. Educ. Res., no. 61, pp. 6180, 2015.

[20] J. Purwono, "Penggunaan Media AudioVisual Pada Mata Pelajaran Ilmu Pengetahuan Alam di Sekolah Menengah Pertama Negeri 1 Pacitan," $J$. Teknol. Pendidik. dan Pembelajaran, vol. 2, no. 2, pp. 127-144, 2014.

[21] A. K. Sari, "Analisis Karakteristik Gaya Belajar VAK (Visual, Auditorial,
Kinestetik) Mahasiswa Pendidikan Informatika Angkatan 2014," Edutic Sci. J. Informatics Educ., vol. 1, no. 1, pp. 1-12, 2014.

[22] M. Sofi, M. Ayub, O. Talib, and N. M. Siew, "The Perceptions of Users Regarding Multimedia Principles in Mobile-Based Japanese Language Learning," 2018.

[23] I. N. M. Bistaman, S. Z. S. Idrus, and S. A. Rashid, "The Use of Augmented Reality Technology for Primary School Education in Perlis, Malaysia," 1st Int. Conf. Green Sustain. Comput. 2017, vol. 1019, p. 12064, 2018.

[24] N. F. Saidin, N. D. Abd Halim, and N. Yahaya, "A Review of Research on Augmented Reality in Education: Advantages and Applications," Int. Educ. Stud., vol. 8, no. 13, pp. 1-8, 2015.

[25] K.-H. Cheng, "Surveying Students' Conceptions of Learning Science by Augmented Reality and their Scientific Epistemic Beliefs," Eurasia J. Math. Sci. Technol. Educ., vol. 14, no. 4, pp. 1147-1159, 2018.

[26] A. Sadiman, Media Pendidikan, Pengertian, Pengembangan, dan Pemanfaatannya. Jakarta: PT. Raja Grafindo Persada, 2011.

[27] S. Ahmadi, S. Khanagha, L. Berchicci, and J. J. P. Jansen, "Are Managers Motivated to Explore in the Face of a New Technological Change? The Role of Regulatory Focus, Fit, and Complexity of Decision-Making," no. March 2017.

[28] A. Ariffin, M. A. Samsudin, A. N. M. Zain, N. Hamzah, and M. E. Ismail, "Effects of Using Graphics and Animation Online Problem-Based Learning on Visualization Skills among Students," IOP Conf. Ser. Mater. Sci. Eng., vol. 203, no. 1, p. 12022, May 2017.

[29] A. Hassan and A. Z. M. Ali, Pembangunan Dan Ujian Kebolehgunaan Animasi Bersegmen Kawalan Pengguna Linear (KPL) Untuk Program Pengajian Diploma Sistem Rangkaian Di Politeknik Malaysia, vol. 3, no. 2. Zenrin, 2015.

[30] M. Wu, "Designing A Digital 
Multimedia Interactive Book for Industrial Metrology Measurement Learning," Mod. Educ. Comput. Sci., vol. 5, pp. 39-46, 2016.

[31] X. Wei, D. Weng, Y. Liu, and Y. Wang, "Teaching based on Augmented Reality for a Technical, Creative Design Course," Comput. Educ., vol. 81, pp. 221-234, 2015.

[32] M. Akçayır, G. Akçayır, H. M. Pektaş, and M. A. Ocak, "Augmented Reality in Science Laboratories: The Effects of Augmented Reality on University Students' Laboratory Skills and Attitudes Toward Science Laboratories," Comput. Human Behav., vol. 57, pp. 334-342, Apr. 2016.

[33] M. E. Ismail, M. I. Irwan, H. Othman, M. H. Amiruddin, and A. Ariffin, "The Use of Animation Video in Teaching to Enhance the Imagination and Visualization of a Student in Engineering Drawing," IOP Conf. Ser. Mater. Sci. Eng., vol. 203, p. 12023, May 2017.

[34] S. Barma, S. Daniel, N. Bacon, M.-A. Gingras, and M. Fortin, "Observation and Analysis of a Classroom Teaching and Learning Practice Based on augmented Reality and Serious Games on Mobile Platforms," Int. J. Serious Games, vol. 2, no. 2, pp. 69-88, 2015.

[35] D. Sulistiyarini and S. Sukardi, "The Influence of Motivation, Learning Styles, Teacher Leadership, and Teaching Intensity On Students'Leaning Outcomes," J. Pendidik. Teknol. dan Kejuru., vol. 23, no. 2, pp. 136-143, 2016.

[36] N. Ngah and E. Zakaria, "Keupayaan Pelajar dalam Menjana Masalah, Menyelesaikan Masalah Matematik dan Sikap Pelajar terhadap Penyelesaian Masalah (Students' Ability in Problems Posing, Mathematical Problem-Solving and Attitudes Towards Problem Solving," J. Pendidik. Mat., vol. 4, no. 1, pp. 1-16, 2016.
[37] A. Suryanto, D. A. Kusumawati, and I. M. H. Sanhoury, "Development of Augmented Reality Technology Based Learning Media of Lathe Machines," $J$. Pendidik. Teknol. dan Kejuru., vol. 24, no. 1, pp. 32-38, 2018.

[38] B. Sharma, B. Steward, S. K. Ong, and F. E. Miguez, "Evaluation of Teaching Approach and Student Learning in a Multidisciplinary Sustainable Engineering Course," J. Clean. Prod., vol. 142,. Part 4, pp. 4032-4040, Jan. 2017.

[39] N. A. A. Majid, F. Yunus, H. Arshad, and M. F. M. Johari, "Mobile augmented reality for teaching structural analysis," Adv. Eng. Informatics, vol. 34, pp. 90-100, 2017.

[40] Y. Turkan, R. Radkowski, A. KarabulutIlgu, A. H. Behzadan, and A. Chen, "Mobile Augmented Reality for Teaching Structural Analysis," $A d v$. Eng. Informatics, vol. 34, pp. 90-100, Oct. 2017.

[41] J. Zhang, Y.-T. Sung, H.-T. Hou, and K.-E. Chang, "The Development and Evaluation of an Augmented RealityBased Armillary Sphere for Astronomical Observation Instruction," Comput. Educ., vol. 73, pp. 178-188, Apr. 2014.

[42] A. Ahmad and N. Jinggan, "Pengaruh Kompetensi Kemahiran Guru dalam Pengajaran terhadap Pencapaian Akademik Pelajar dalam Mata Pelajaran Sejarah," JuKu J. Kurikulum Pengajaran Asia Pasifik, vol. 3, no. 2, pp. 1-11, 2017.

[43] R. A. Razak and M. A., "Rahman, Pembinaan Media Pengajaran Berasaskan Multimedia Di Kalangan Guru ICTL", ЈuKu J. Kurikulum Pengajaran Asia Pasifik, vol. 1, no. 2, 2017. 